удк 534.75

\title{
ПРИНЦИПЫ ПОСТРОЕНИЯ СЛУХОВОГО ЭХОСКОПА ДЛЯ ДИАГНОСТИКИ СРЕДНЕГО УХА ЧЕЛОВЕКА
}

\author{
ДИДКОВСКИЙ В. С., НАЙДА С. А. \\ Национальный технический университет Украинь \\ «Киевский политехнический институт», \\ Украина, Киев, 03056, пр-т Победы 37
}

\begin{abstract}
Аннотация. В работе на примере разработки лабораторного образца слухового эхоскопа сформулированы принципы построения диагностического прибора с повышенной точностью определения акустического импеданса. Прибор позволяет путем измерения коэффициента отражения звука от барабанной перепонки оценить состояние среднего уха человека не только качественно, но и количественно, и определить соответствующие параметры
\end{abstract}

Ключевые слова: среднее ухо; коэффициент отражения; электроакустический преобразователь; звукопроводящая трубка

\section{ВВЕДЕНИЕ}

Слуховой эхоскоп - прибор для ранней (функциональной) объективной диагностики нарушений слуха, который применяется как для диагностики среднего уха человека без участия сенсоневральной системы [1], так и в тимпанопластике для подбора материалов косточковых протезов [2].

На основании измеренной частотной зависимости коэффициента отражений звука от барабанной перепонки возможно определить гибкость барабанной перепонки (м/Н), резонансные частоты механической системы уха (Гц), массу слуховых косточек (мг), отношение активной составляющей механического импеданса уха к импедансу воздуха, коэффициент трансформации акустического давления слуховыми косточками в жидкость улитки внутреннего уха, а также фактор нормы - инвариант среднего уха человека в норме [3].
Предлагаемый эхоскоп обладает рядом преимуществ по сравнению с многочастотными импедансометрами, включая реактансные, которые широко используются для диагностики среднего уха человека в настоящее время. Среди них следующие:

- отсутствие замкнутого объема внешнего слухового прохода между ушной вставкой и барабанной перепонкой и, как следствие, повышенная точность определения акустического импеданса и дифференциации межсубъектных отклонений различных параметров уха от средних отклонений в результате нарушений в системе среднего уха;

- значительно меньшие средние по времени уровни звукового давления;

- отсутствие пневмосистемы, которая может приводить к повреждению слухового аппарата новорожденных.

Принцип действия слухового эхоскопа состоит в излучении коротких звуковых импульсов в трубку малого, по сравнению с длиной 